\title{
Evaluation of Antioxidant Activity of fresh Lemon (Citrus lemon L.) peel in Marrakech, Kenitra cities of Morocco and Taiz of Yemen
}

\author{
Khaled Abdu ${ }^{1, *}$, Rahma Erahioui ${ }^{2}$, Amina Moutawalli ${ }^{3}$, Ahmed Zahidi ${ }^{3}$, Khadija Khedid ${ }^{4}$ and $^{\text {Kha }}$ \\ Said Ibn Ahmed ${ }^{1}$ \\ ${ }^{1}$ Materials, Electrochemistry and Environment Laboratory Ibn Tofail University Po Box 133, Kenitra, \\ Morocco \\ ${ }^{2}$ Laboratory of Agrophysiology, Biotechnology, Environment, and Quality Ibn Tofail University \\ Po Box 133 Kenitra, Morocco \\ ${ }^{3}$ Department of Drug Sciences, Laboratory of Medicinal Chemistry, Faculty of Medicine and Pharmacy, \\ Mohammed V University Po Box 8007 Rabat, Morocco \\ ${ }^{4}$ Laboratory of Bacteriology, National Institute of Health, Po Box 763 Rabat, Morocco
}

\begin{abstract}
The principal objective of this study was to appraise the variation of antioxidant activity, total phenols, and total flavonoids of fresh lemon peel from regions located Marrakech and Kenitra in Morocco and a region Taiz in Yemen. The test of polyphenol was performed from extracts that were measured using the Folin-Ciocalteu technique. Also, an analysis of Flavonoid was performed of was measured by using the aluminum chloride. The Free radical scavenging activity of lemon extracts was measured by 2,2'-Diphenyl-1-picrylhydrazyl hydrate (DPPH).

The DPPH radical scavenging activity of ethanolic extract of fresh lemon peel found to be highest at $200 \mu 1$ concentration, which was 77. $15 \% ; 67.88 \% ; 37.74 \%$. Through it, 50\% inhibition (IC50) was obtained to be 92 . 04; 153. 55 and $215.407 \mu \mathrm{g} / \mathrm{ml}$ in Marrakech, Kenitra, and Taiz, respectively. As well, the values radical scavenging activity of methanolic extract of the same concentration, which are $82,77 \%, 53,33 \%$, and $47,5 \%$. Through it, 50\% inhibition (IC50) was obtained to be $145.6 ; 179.17$ and 274.899 $\mu \mathrm{g} / \mathrm{ml}$ in Marrakech, Kenitra, and Taiz, respectively. But regarding the values radical scavenging activity of essential oil of the same concentration, which is $63.77 \%, 42.19 \%$, and 80.25\%. Through it, 50\% inhibition (IC50) was obtained to be $155.54 ; 271.158$ and $101.31 \mu \mathrm{g} / \mathrm{ml}$ in Marrakech, Kenitra, and Taiz, respectively. According to the results obtained in our study, the antioxidant activity increases with increased polyphenols and IC50 deficiency in Marrakech, Kenitra, and Taiz.
\end{abstract}

Keywords: Citrus Limon; antioxidant activity; polyphenols; flavonoids; radical scavenging activity.

\section{Introduction}

Citrus is a variety of fruits and belongs to [Rutaceae family]، it contains 52 species and 17 pieces ${ }^{1}$. The best known is lemon, mandarin, and sour orange, which have nutritional value and health benefits ${ }^{2}$. Citrus fruits also play an active role in preventing chronic diseases, diabetes, blood pressure, and some types of cancer ${ }^{3}$. It is also present in cosmetics such as soaps, perfumes, shampoos, and toiletries ${ }^{4}$. Citrus is classified as one of the most productive crops in the world, with an annual production of $102 \times 106$ tons. Lemon represents the third most crucial citrus cultivation after oranges and mandarin, with global production reaching 420,000 tons annually ${ }^{5}$.
Morocco, Portugal and Spain are citrus producers in the Mediterranean region, with an average annual production of 10 million tons ${ }^{6}$.

Fruits and vegetables are natural sources of phenolic compounds (10). Therefore, the citrus peel contains flavonoids, phenolic compounds, essential oils, vitamins, and minerals ${ }^{7-8}$.

It is well known that phenolic and secondary metabolites with associated double bonds usually exhibit antioxidant properties 9 .

\section{Experimental}

Citrus fruits were obtained at the beginning of the 
harvest season in November 2019 from Morocco (Marrakech and Kenitra) and Yemen (Taiz). The study was conducted on the collected fruits at the Regional Center for Agricultural Research in Kenitra, Marrakech.

\subsection{Preparation of Essential Oil}

The essential oil content was determined by fresh Lemon peels by steam distillation ${ }^{10}$. The mixture was preheated for 6 hours at $4^{\circ} \mathrm{C}$. Therefore, the yield was obtained by the relation between the mass of lemon peels and that of the essential oil.

\subsection{Preparation of extracts}

The solvents Ethanol and Methanol were extracted from the lemon peels using (Soxhlet technique).

It was heated for 5 hours at $4^{\circ} \mathrm{C}$, according to Lin study ${ }^{11}$.

\subsection{The chemical composition of fresh Citruslimon peel}

The essential oil of fresh citrus lemon peel was an Analysed of by employing gas chromatography-mass spectrometry (GC-MS) along with the mass spectrometer (Q-8 MS ion trap) by application of Adams data ${ }^{12}$.

\subsubsection{Determination of total polyphenol content}

The polyphenol was assessed of C.limon peels by the method the Folin-Ciocalteu according to Lister and Wilson ${ }^{13} \cdot 0,5 \mathrm{~mL}$ were accoutred from the ethanolic extracts and methanolic extracts in Morocco exactly from Marrakech, Kenitra cities and from Taize city in Yemen, we added $4 \mathrm{~mL}$ of sodium carbonate $(7.5 \%, \mathrm{w} / \mathrm{v})$ and added 2,5 mL of Folin Cio calteu reagent, and also dilute it with distilled water by $1: 10$ ratio. Then the samples were incubated at $45^{\circ} \mathrm{C}$ for 30 minutes for the development of a blue color. The absorbance measurements were made at $765 \mathrm{~nm}$ using a UV-Vis spectrophotometer in comparison with the blank solution. Under the same conditions, the standard curve of Gallic acid was obtained over a concentration range of $0-500(\mu \mathrm{g} / \mathrm{ml})$. The values of phenolic contents were expressed as Gallic acid equivalent (mg GAE/g extract).

\subsubsection{Determination of Total Flavonoid content}

The test flavonoids were performed of ethanolic and methanolic extracts of the fresh Lemon peels in Marrakech, and Kenitra Morocco cities and Yemen
Taiz city by the employment of the aluminum chloride colorimetric according to Ordon $14.0,5 \mathrm{~mL}$ of each sample was mixed with $0.5 \mathrm{~mL}$ of 0,2 aluminum chloride $10 \%$ and diluted with Methanol to a ratio of $96 \%, 0,2 \mathrm{ml}$ potassium acetate, and $5 \mathrm{ml}$ of water distilled. Also, the mixture was incubated at a temperature of $40^{\circ} \mathrm{C}$ for $30 \mathrm{~min}$. The absorbance measurements were synthetic, at $420 \mathrm{~nm}$ by utilizing a -Vis spectrophotometer in comparison with the blank solution. Beneath the same conditions, the standard curve of quercetin was gained over a concentration range of $0-100(\mu \mathrm{g} / \mathrm{ml})$. The values of flavonoid contents were expressed as quercetin equivalent (mg GAE/g extract).

\subsection{Antioxidant Activity (AA)}

The Free radical scavenging activity of citrus lemon extracts was measured by 2,2'-Diphenyl-1picrylhydrazyl hydrate (DPPH) ${ }^{15}$. Thus, $(0.2 \mathrm{mM})$ was prepared by dissolving $7.8 \mathrm{mg}$ of DPPH in $100 \mathrm{~mL}$ methanol at room temperature for $2 \mathrm{~h}$ in a dark place to complete the reaction. The different concentrations $(20,40,60,80,120,140,160,180$ and $200 \mu \mathrm{g} / \mathrm{ml}$ ) of solutions of each extract were prepared by the serial dilution of the stock solution $(4 \mathrm{mg} / \mathrm{ml})$ of citrus Limon peels extract. To each $0.5 \mathrm{ml}$ extract solution, $2.5 \mathrm{ml}$ of DPPH solution was added. A control was prepared by mixing $0.5 \mathrm{ml}$ distilled water and $2.5 \mathrm{ml} 0.1 \mathrm{mM}$ DPPH solution. These samples were shaken well and kept in the dark for 30 minutes at room temperature. The absorbance was measured at $517 \mathrm{~nm}$ against the blank solution consisting of $2.5 \mathrm{ml} \mathrm{MeOH}$ and $0.5 \mathrm{ml}$ distilled water. Percentage of DPPH Scavenging Activity determined as follows $\%$ DPPH radical scavenging $=[$ (absorbance of control - absorbance of the test sample) $\div$ (absorbance of control)] $\times 100$.

\section{Results}

The results of our current study are illustrated clearly below the yield, composition chemical, polyphenols, and evaluation of Antioxidant Activity of fresh Lemon (Citrus lemon) peel in Marrakech and Kenitra cities Morocco and Yemen.

\subsection{The yield of fresh lemon peel extracts}

The yield rate of essential oil HE, methanol extract $\mathrm{EM}$, and ethanol extract EE were $0.78 \% ; 9.8 \%$; $10.05 \%, 0.64 \%, 8.3 \%, 8.9 \%$ and $0,90 \% ; 8,8 \%, 8,6 \%$ in Marrakech, Kenitra, Taize respectively Table1.

Table 1. The yield rate of fresh Citrus limon peel in Marrakech, Kenitra, and Taize.

\begin{tabular}{|c|c|c|c|c|c|c|c|c|c|}
\hline \multirow{2}{*}{ Extract } & \multicolumn{3}{|c|}{ Marrakech } & \multicolumn{3}{c|}{ Kenitra } & \multicolumn{3}{c|}{ Taize } \\
\cline { 2 - 28 } & HE & EM & EE & HE & EM & EE & HE & EM & EE \\
\hline Yield R \% & 0.78 & 9.8 & 10.05 & 0.64 & 8.3 & 8.9 & 0,90 & 8,2 & 8,6 \\
\hline
\end{tabular}

Key: $\boldsymbol{H E}$ : essential oil, EE: ethanol extract, EM: methanol extract 
Table 2. Chemical compounds of essential oil of fresh Citrus limon peel for three cities Kenitra, Marrakech, and Taize.

\begin{tabular}{|c|c|c|c|}
\hline \multirow{2}{*}{ Chemical compounds } & Marrakech & Kenitra & Taize \\
\cline { 2 - 4 } & Citrus limon HE & Citrus limon HE & Citrus limon HE \\
\hline \multirow{2}{*}{$\beta-$ Myrcene } & P $\%$ & P \% $\%$ \\
\hline D-Limonene & 1,20 & 2,67 & 0,14 \\
\hline Linalyl Acetate & 39,49 & 29,19 & 9,41 \\
\hline$\alpha$-Terpineol & 14,07 & 14,54 & 3,86 \\
\hline$\alpha$-Pinene & 4,90 & 10,47 & 9,40 \\
\hline$\beta$-Pinene & 7,93 & 0,64 & 0,11 \\
\hline Carvacrol & 5,54 & 4,69 & 0,86 \\
\hline p- Terpineol & 1,25 & 0,06 & 10,32 \\
\hline Total & 3,51 & 0,11 & 1,15 \\
\hline
\end{tabular}

Chemical analysis has shown the following values $99,87 \%, 98,84 \%$, and $99,20 \%$ components for the essential oil of Marrakech, Kenitra, and Taize, respectively. The major component of the essential oil in Marrakech D-Limonene, which has a rate of $39,49 \%$. While the major component of the essential oil in Kenitra D-Limonene which has a rate of $29,19 \%$. While the major component of the essential oil in Taize Carvacrol which has a rate of $10,32 \%$.

\subsection{Determination of polyphenols content}

The standard curve $(\mathrm{y}=0.028 \mathrm{x}+0,0632, \mathrm{r} 2=0.9994)$ for the determination of total polyphenol content was obtained by referring to a calibration curve carried out with gallic acid $\mu \mathrm{g} / \mathrm{ml}$ (Table 3), (Figure 1). The concentrations of total polyphenols obtained were presented in (Table 4) (Figure 2), they are expressed in $\mu \mathrm{g} \mathrm{EAG} / \mathrm{g}$ ES.

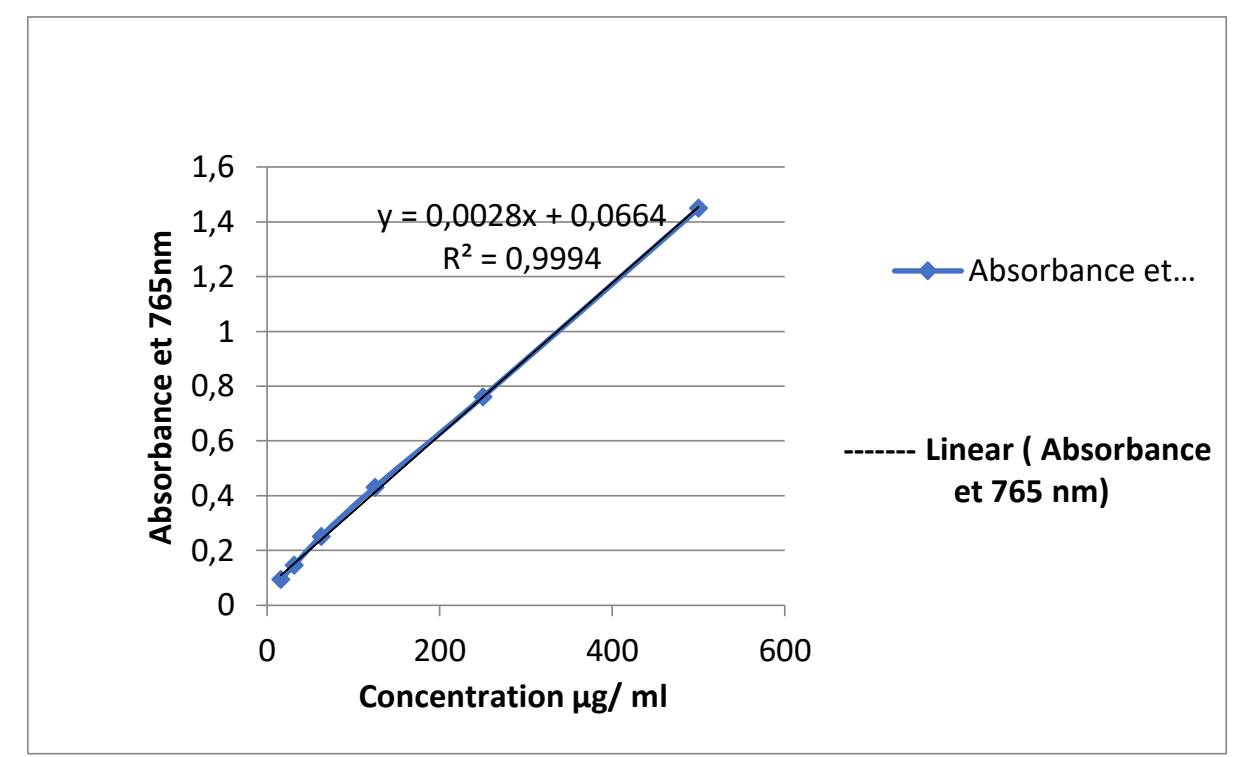

Figure 1. Calibration curve of standard Galic Acid

Table 3. Absorbance of standard Acid Galic.

\begin{tabular}{|c|c|}
\hline Conc. $(\boldsymbol{\mu g} / \mathbf{m l})$ & Absorbance at $\mathbf{7 6 5} \mathbf{n m}$ \\
\hline 500 & 1,45 \\
\hline 250 & 0,761 \\
\hline 125 & 0,431 \\
\hline 62,5 & 0,251 \\
\hline 31,25 & 0,145 \\
\hline
\end{tabular}




\begin{tabular}{|c|c|}
\hline 15,625 & 0,094 \\
\hline 7,81 & 0,075 \\
\hline
\end{tabular}

Table 4. The determination Polyphenol content of extracts Ethanol and Methanol of fresh Citrus limon peels.

\begin{tabular}{|c|c|c|c|c|c|c|}
\hline Sample/Extracts & $\begin{array}{c}\text { Sample } \\
\text { solution } \\
\boldsymbol{\mu g / m l}\end{array}$ & $\begin{array}{c}\text { Weight of } \\
\text { dry } \\
\text { Extract }\end{array}$ & $\begin{array}{c}\text { Absorbance } \\
\text { at 765nm }\end{array}$ & $\begin{array}{c}\text { GAE } \\
\text { ConcC } \\
\boldsymbol{\mu g} / \mathbf{m l}\end{array}$ & $\begin{array}{c}\text { GAE } \\
\text { ConcC } \\
\mathbf{m g} / \mathbf{m L}\end{array}$ & $\begin{array}{c}\text { TPC as } \\
\mathbf{G A E} \boldsymbol{\mu g} / \mathbf{m l}\end{array}$ \\
\hline E M & 1000 & 0.001 & 0,238 & 62,42857 & 0,0624 & 62,428571 \\
\hline EK & 1000 & 0.001 & 0,224 & 57,42857 & 0,0574 & 57,42857 \\
\hline EY & 1000 & 0.001 & 0,219 & 55,64285 & 0,0556 & 55,64285 \\
\hline MM & 1000 & 0.001 & 0,227 & 58,5 & 0,0585 & 58,5 \\
\hline MK & 1000 & 0.001 & 0,221 & 56,35714 & 0,0563 & 56,35714 \\
\hline MY & 1000 & 0.001 & 0,213 & 53,5 & 0,0535 & 53,5 \\
\hline
\end{tabular}

Key: HE: essential oil, EE: ethanol extract, EM: methanol extract

EM: Ethanol extract Marrakech MM: Methanol extract Marrakech

EK: Ethanol extract Kenitra MK: Methanol extract Kenitra

MY: Methanol extract Yemen EY: Ethanol extract Yemen

The content of total polyphenols in the ethanolic extracts shows different results, whose dominant is Marrakech by $62.42 \mu \mathrm{g} / \mathrm{ml}$, followed by the value of Kenitra $57.428 \mu \mathrm{g} / \mathrm{ml}$ and the lowest result in Yemen $55.642 \mu \mathrm{g} / \mathrm{ml}$. Also, for the content of total polyphenols in the Methanolic extracts, we find a high percentage in Marrakech by $58.562 \mu \mathrm{g} / \mathrm{ml}$, followed by the value of Kenitra $56.357 \mu \mathrm{g} / \mathrm{ml}$ and the lowest result in Yemen $53.5 \mu \mathrm{g} / \mathrm{ml}$.

\subsection{Determination of flavonoid}

The standard curve $(y=0.0043 x+0,0282, r 2=0.9705)$ for the determination of total flavonoid content was obtained by referring to a calibration curve carried out with Quercetin $\mu \mathrm{g} / \mathrm{ml}$ (Table 5) (Figure 3). The concentrations of total flavonoid obtained were presented in (Table 6) (Figure 4), they are expressed in $\mu \mathrm{g}$ EAG / g ES.

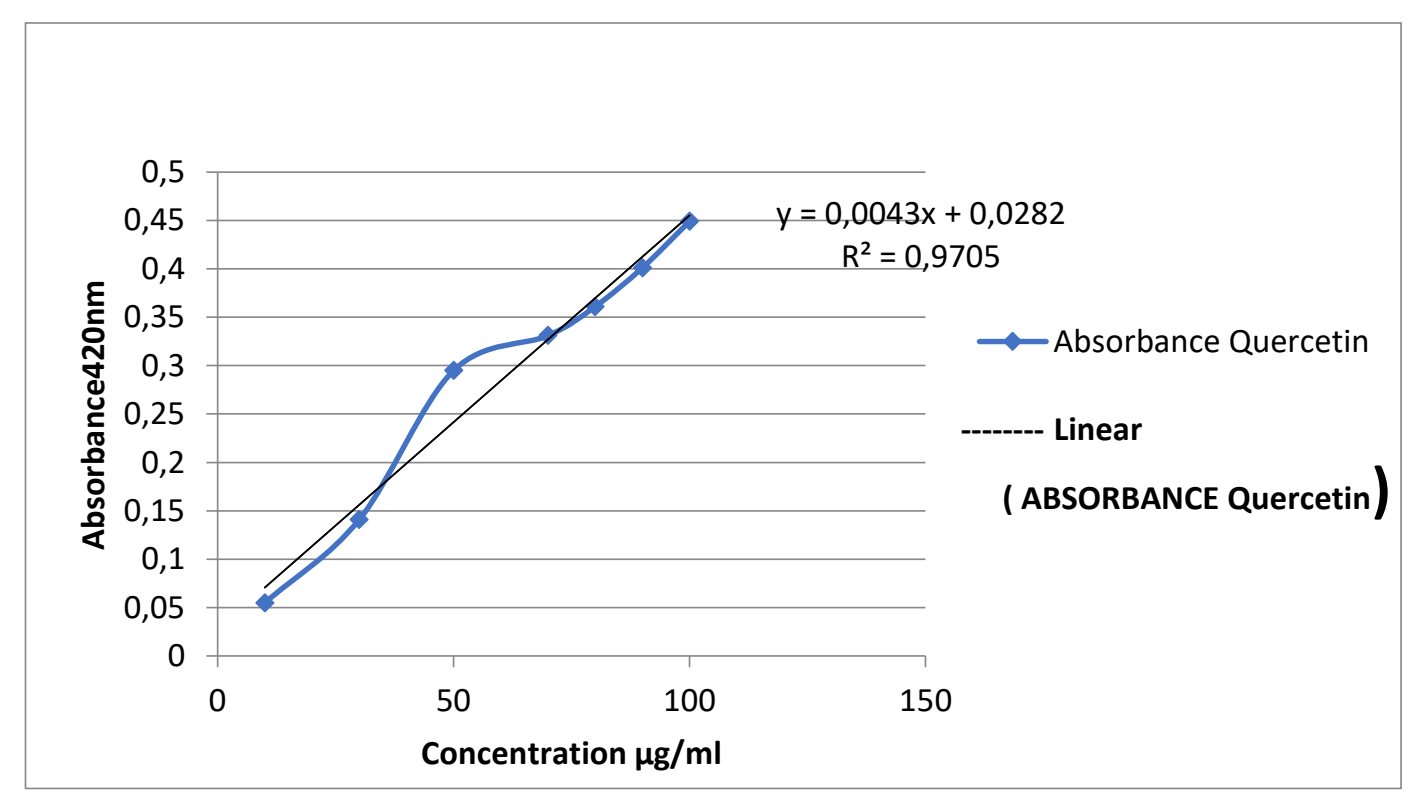

Figure 2. Calibration curve of standard Quercetin glycoside 
Table 5. Absorbance of standard Quercetin.

\begin{tabular}{|c|c|}
\hline Conc. $(\boldsymbol{\mu g} / \mathbf{m l})$ & Absorbance at $\mathbf{4 2 0} \mathbf{~ n m}$ \\
\hline 10 & 0,055 \\
\hline 30 & 0,141 \\
\hline 50 & 0,295 \\
\hline 70 & 0,331 \\
\hline 80 & 0,361 \\
\hline 100 & 0,401 \\
\hline
\end{tabular}

Table 6. Determination flavonoid content of extracts ethanol and Methanol of fresh Citrus Limon peels.

\begin{tabular}{|c|c|c|c|c|c|c|}
\hline Sample/Extracts & $\begin{array}{c}\text { Sample } \\
\text { solution } \\
\boldsymbol{\mu g} / \mathbf{m l}\end{array}$ & $\begin{array}{c}\text { Weight of dry } \\
\text { Extract } \mathbf{m g} / \mathbf{m l}\end{array}$ & $\begin{array}{c}\text { Absorbance } \\
\mathbf{a t} \mathbf{7 6 5 n m}\end{array}$ & $\begin{array}{c}\text { GAE } \\
\mathbf{C o n c C} \\
\boldsymbol{\mu g} / \mathbf{m L}\end{array}$ & $\begin{array}{c}\text { GAE } \\
\mathbf{C o n c C} \\
\mathbf{m g} / \mathbf{m L}\end{array}$ & $\begin{array}{c}\text { TPC as } \\
\mathbf{G A E} \\
\boldsymbol{\mu g} / \mathbf{m l}\end{array}$ \\
\hline $\mathbf{E ~ M}$ & 1000 & 0.001 & 0,393 & 84,8372 & 0,0848 & 84,8372 \\
\hline $\mathbf{E K}$ & 1000 & 0.001 & 0,269 & 56 & 0,056 & 56 \\
\hline $\mathbf{E Y}$ & 1000 & 0.001 & 0,219 & 44,37209 & 0,0443 & 44,37209 \\
\hline MM & 1000 & 0.001 & 0,323 & 68,5581 & 0,0685 & 68,5581 \\
\hline MK & 1000 & 0.001 & 0,224 & 45,53488 & 0,0455 & 45,53488 \\
\hline MY & 1000 & 0.001 & 0,119 & 21,11627 & 0,0211 & 21,11627 \\
\hline
\end{tabular}

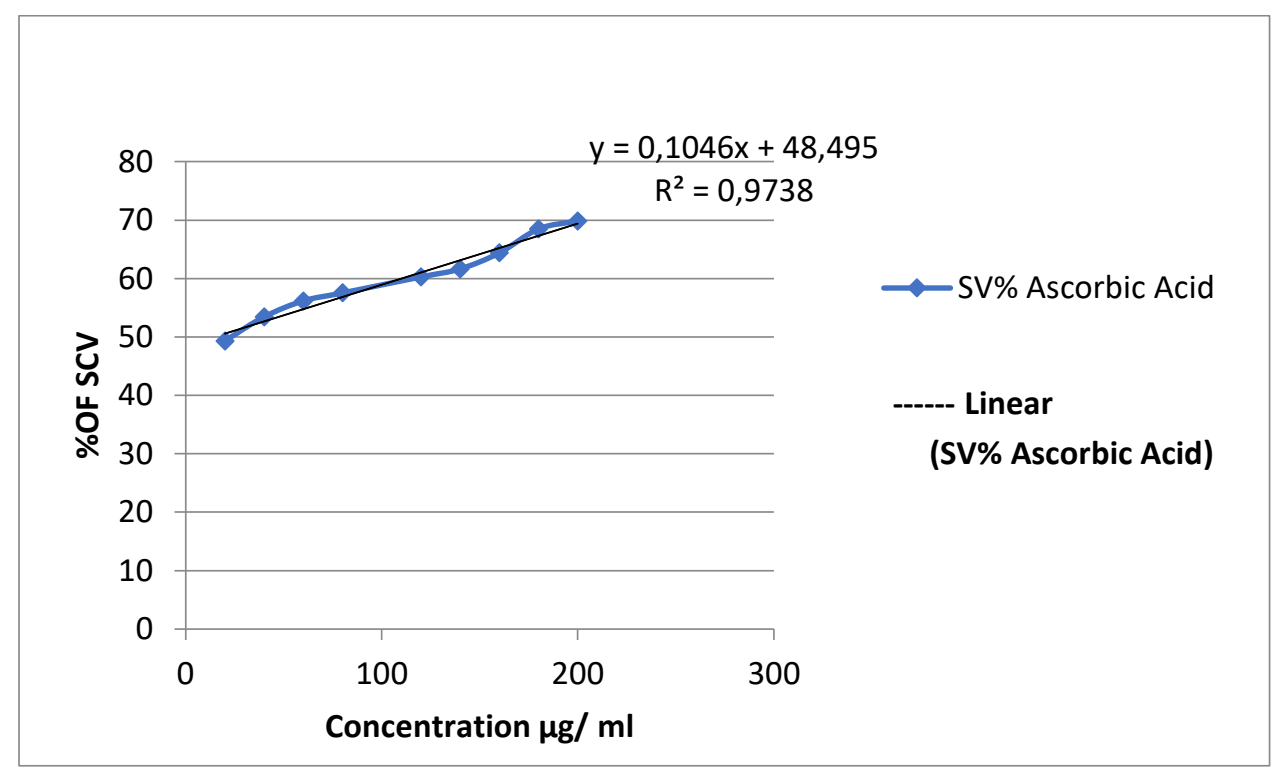

Figure 3. Calibration curve of standard Ascorbic Acid

The content of total flavonoid in the ethanolic extracts shows different results in Table 6 and Figure 4; the highest one is Marrakech by $84.837 \mu \mathrm{g} / \mathrm{ml}$, followed by the value of Kenitra $56 \mu \mathrm{g} / \mathrm{ml}$ and the lowest result in Yemen $44.372 \mu \mathrm{g} / \mathrm{ml}$. Also, for the content of total polyphenols in the Methanolic extracts, we find a high percentage in Marrakech by $68.558 \mu \mathrm{g} / \mathrm{ml}$, followed by the value of Kenitra $45.534 \mu \mathrm{g} / \mathrm{ml}$ and the lowest result in Yemen $21.116 \mu \mathrm{g} / \mathrm{ml}$.

\subsection{Radical scavenging activities (DPPH)}

The Radical scavenging activities (DPPH) were found of standard ascorbic acid at different concentrations was found (Tables 7) (Figure 5). Also, The Radical scavenging activities (DPPH) of essential oil and extracts (Table 8) (Figure 6, 7). That is, by measuring the absorbance at the wavelength of $517 \mathrm{~nm}$ for different concentrations of extracts and the control. 


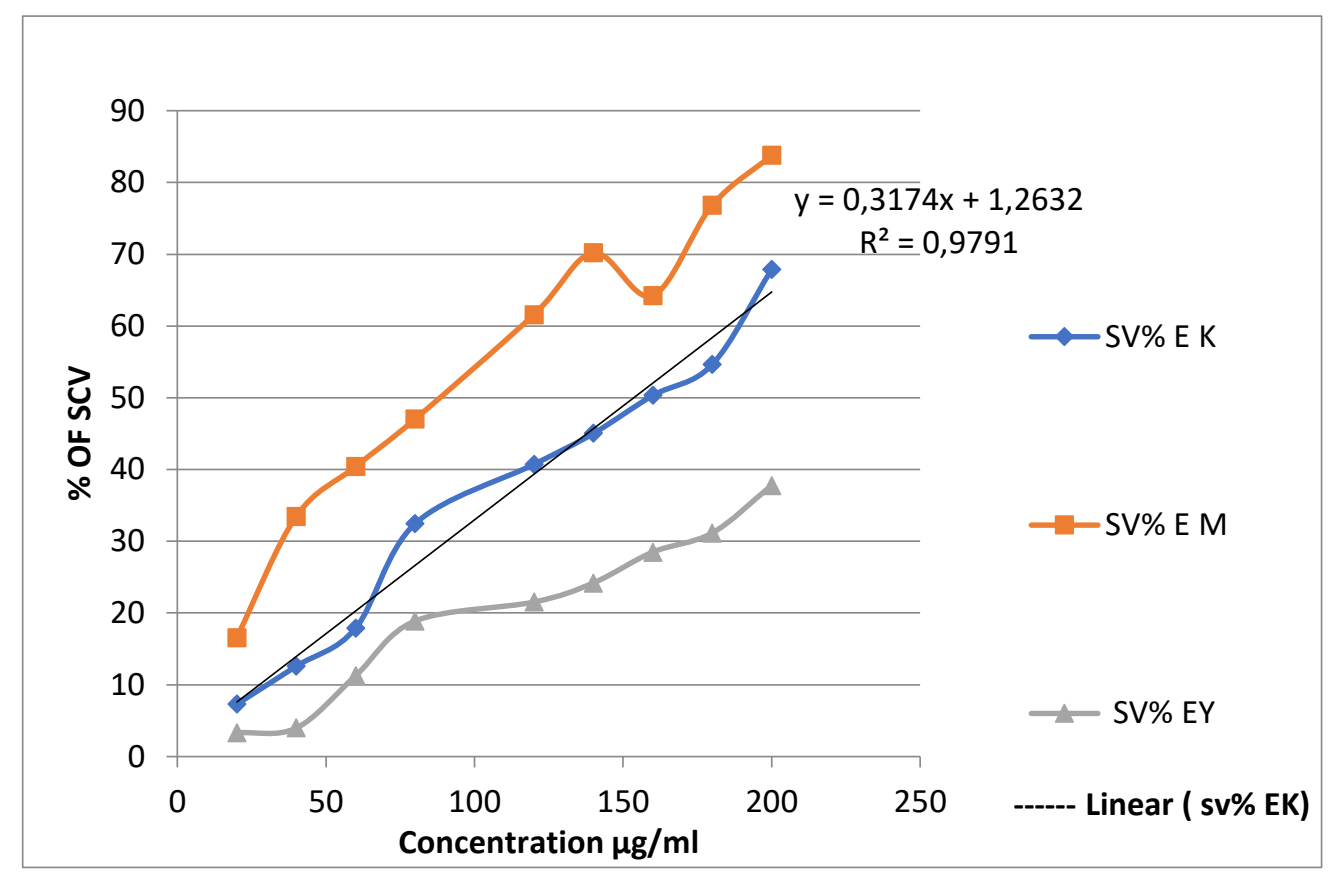

Figure 4. Calibration curve of DPPH scavenging activity of ethanolic extract of fresh citrus limon peels for three regions.

Table 7. \% DPPH Scavenging Activity of standard Ascorbic Acid.

\begin{tabular}{|c|c|c|}
\hline Standard & \multicolumn{2}{|c|}{ Acid ascorbic } \\
\hline Con $\boldsymbol{\mu g} / \mathbf{m l}$ & Absorbance $517 \mathrm{~nm}$ & SCV\% \\
\hline $\mathbf{2 0}$ & 0,037 & 49,31 \\
\hline $\mathbf{4 0}$ & 0,034 & 53,42 \\
\hline $\mathbf{6 0}$ & 0,032 & 56,16 \\
\hline $\mathbf{8 0}$ & 0,031 & 57,53 \\
\hline $\mathbf{1 2 0}$ & 0,029 & 60,27 \\
\hline $\mathbf{1 4 0}$ & 0,028 & 61,64 \\
\hline $\mathbf{1 6 0}$ & 0,026 & 64,38 \\
\hline $\mathbf{1 8 0}$ & 0,022 & 68,49 \\
\hline $\mathbf{2 0 0}$ & 0,022 & 69,86 \\
\hline
\end{tabular}

The DPPH radical scavenging activity of standard ascorbic acid was found to be highest at $200 \mu 1$

concentration, which was $69.68 \%$.

Table 8. The Radical scavenging activities (DPPH) of essential oil and extracts of fresh Citrus limon peel in Marrakech, Kenitra, and Taize (Yemen).

\begin{tabular}{|c|c|c|c|c|c|c|c|c|c|}
\hline \multirow{3}{*}{$\begin{array}{c}\begin{array}{c}\text { Extract } \\
\text { sample }\end{array} \\
\text { Con } \mu \mathrm{g} / \mathrm{ml}\end{array}$} & \multicolumn{3}{|c|}{ Marrakech } & \multicolumn{3}{|c|}{ Kenitera } & \multicolumn{3}{|c|}{ Taize } \\
\hline & \multicolumn{3}{|c|}{ Ethanol } & \multicolumn{3}{|c|}{ Ehtanol } & \multicolumn{3}{|c|}{ Ehtanol } \\
\hline & $\begin{array}{c}\mathrm{Abc} \\
517 \mathrm{~nm}\end{array}$ & SV\% & $\begin{array}{c}\mathrm{IC} 50 \\
\mu \mathrm{g} / \mathrm{ml}\end{array}$ & $\begin{array}{c}\mathrm{Abc} \\
517 \mathrm{~nm}\end{array}$ & SV\% & $\begin{array}{l}\text { IC50 } \\
\mu \mathrm{g} / \mathrm{ml}\end{array}$ & $\begin{array}{c}\mathrm{Abc} \\
517 \mathrm{~nm}\end{array}$ & SV\% & $\begin{array}{l}\mathrm{IC50} \\
\mu \mathrm{g} / \mathrm{ml}\end{array}$ \\
\hline 20 & 0,282 & 6,622 & \multirow{3}{*}{92,04} & 0,280 & 7,28 & \multirow{3}{*}{153,55} & 0,292 & 3,311 & \multirow{3}{*}{215,407} \\
\hline 40 & 0,248 & 17,88 & & 0,264 & 12,58 & & 0,290 & 3,97 & \\
\hline 60 & 0,223 & 26,15 & & 0,248 & 17,88 & & 0,268 & 11,25 & \\
\hline
\end{tabular}




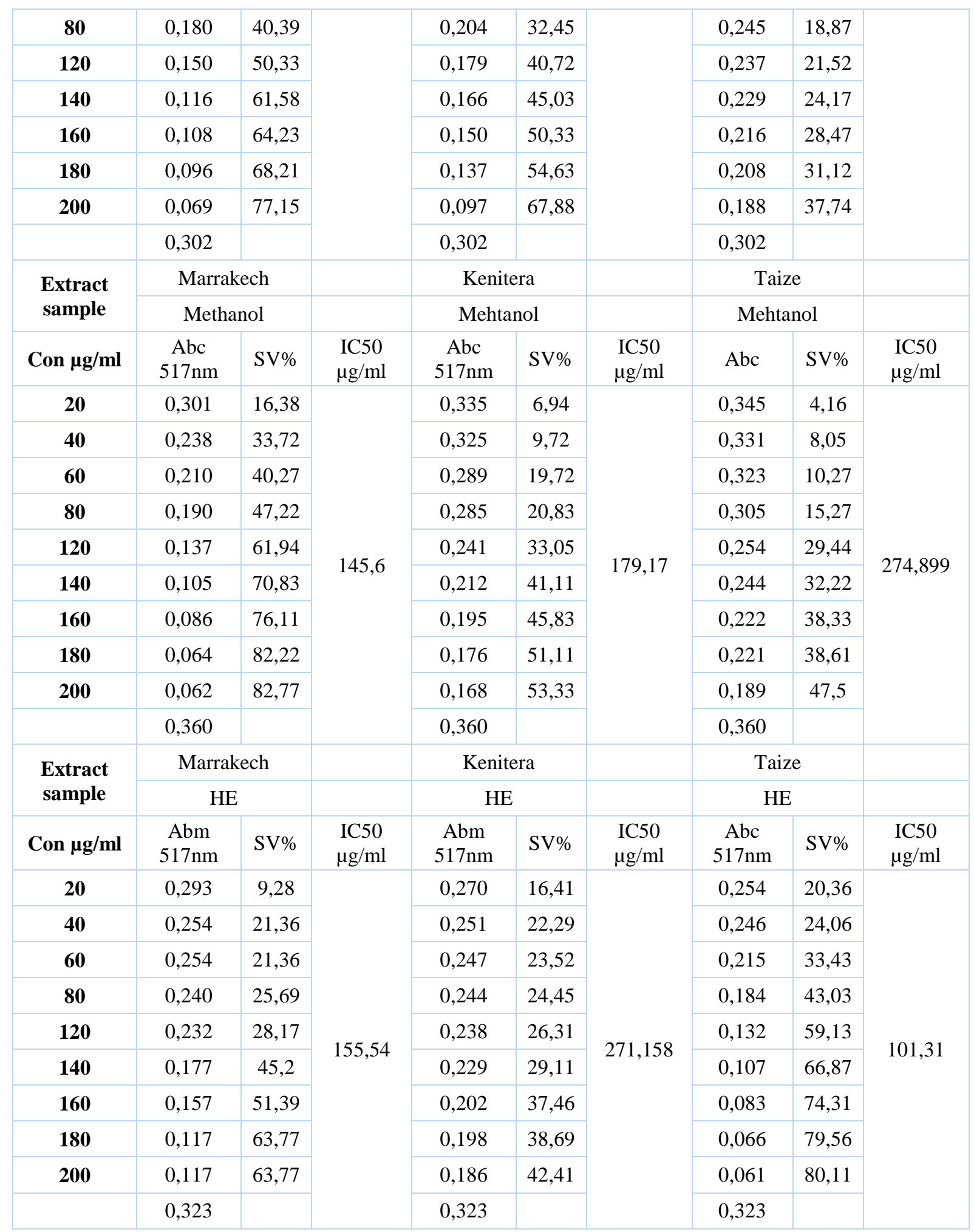




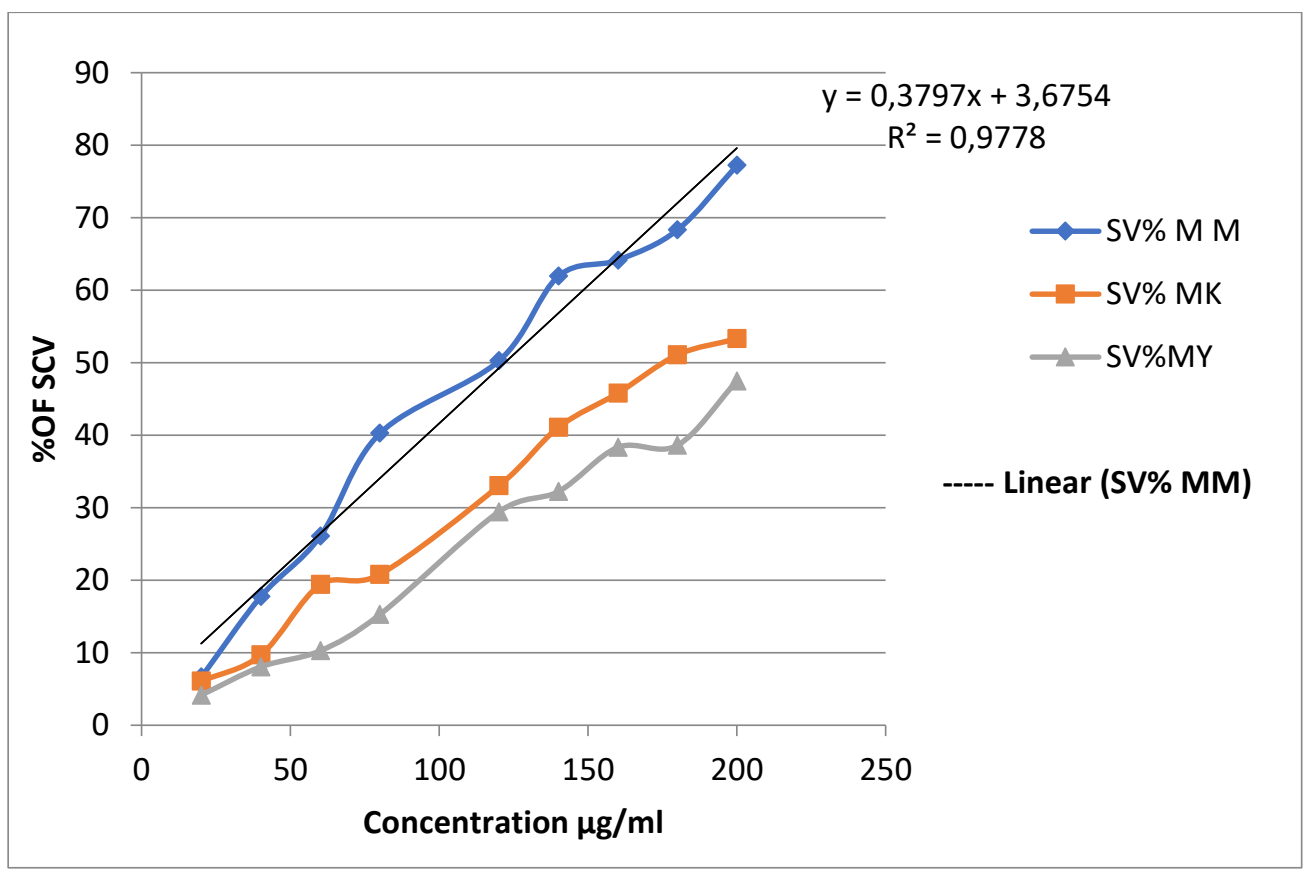

Figure 5. Calibration curve of scavenging activity of methanolic extract of fresh citrus limon peels for three regions.

SV\%EM: percentage scavenging activity of Ethanol extract Marrakech

SV\%EK: percentage scavenging activity of Ethanol extract Kenitra

SV\%EY: percentage scavenging activity of Ethanol extract Yemen

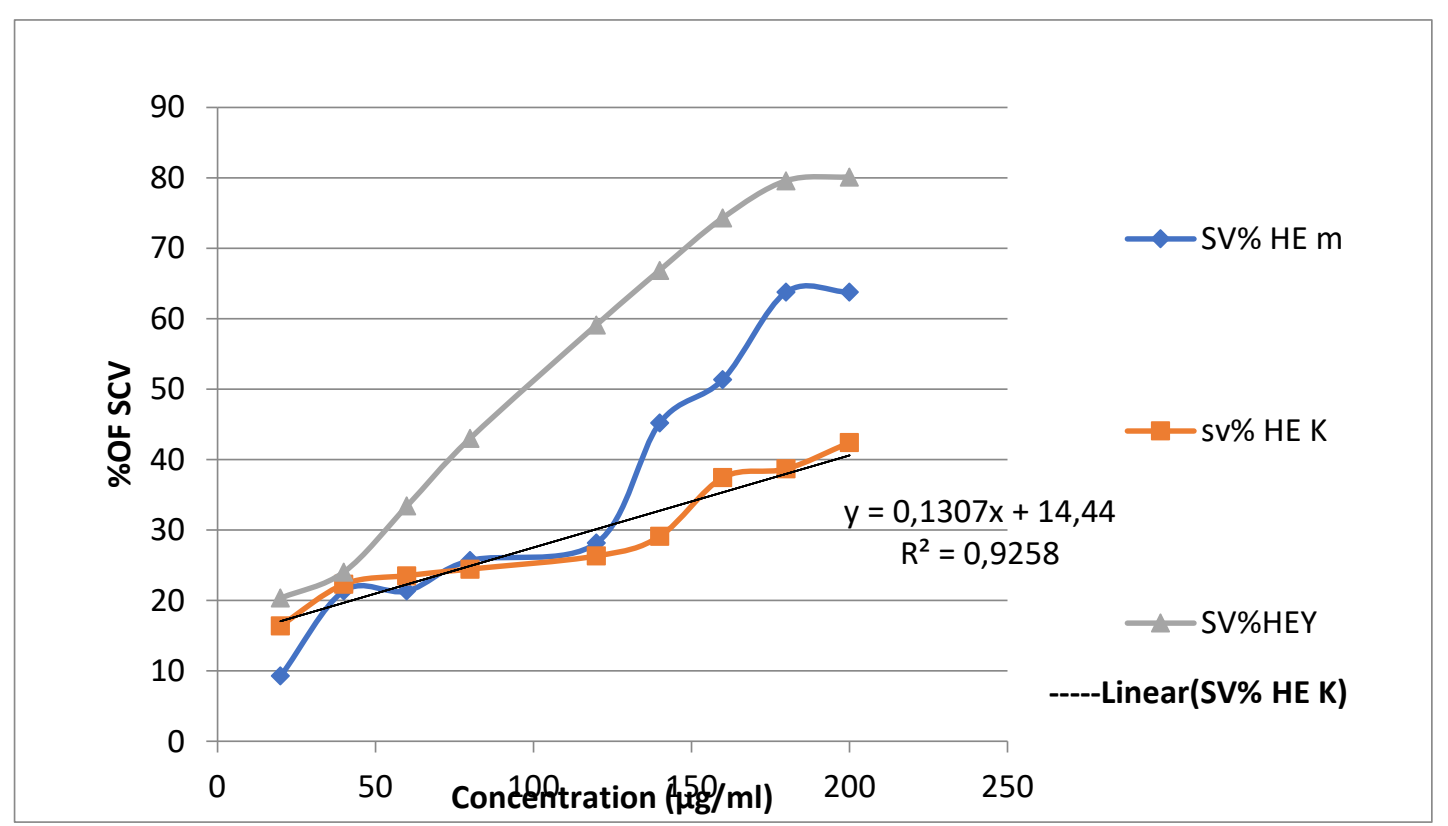

Figure 6. Calibration curve of scavenging activity of essential oil of fresh citrus limon peels for three regions.

SV\%MM: percentage scavenging activity of Methanol extract Marrakech

SV\%MK: percentage scavenging activity of Methanol extract Kenitra

SV\%MY: percentage scavenging activity of Methanol extract Yemen

\section{Discussion}

It is clear from the obtained results in Table 1. The yield rate of essential oil was $(0.90 \%)$ in Yemen higher than the yield in the Marrakech, it was $(0.78 \%)$ higher than the yield in the Kenitra it was $(0.64 \%)$.
While the yield rate of extracting methanolic (EM) and extracted ethanolic (EE), it was (9.8\%) and $(10.05 \%)$ in Marrakech higher than the yield in the Kenitra, it was $(8.3 \%)$ and $(8.9 \%)$ in Kenitera higher than the yield in the Taiz, it was $(8.2 \%)$ and $(8.6 \%)$ respectively. Therefore, the yield ratio of extraction 
ethanol is higher than extraction methanol and essential oils.

The DPPH radical scavenging activity of ethanolic extract of fresh Citrus limon peels was found to be highest at $200 \mu$ l concentration, which was $(77.15 \%)$; (67.88 \%); (37.74\%). Through it, 50\% inhibition (IC50) was obtained to be (92.04); (153.55) and (215.407) $\mu \mathrm{g} / \mathrm{ml}$ in Marrakech, Kenitra, and Taiz, respectively. As well, the values radical scavenging activity of methanolic extract of the same concentration, which are $(82.77 \%) ;(53.33 \%)$ and $(47.5 \%)$.

Through it, 50\% inhibition (Marrakech obtained to be (92.04); (153.55) and (215.407) $\mu \mathrm{g} / \mathrm{ml}$ in Marrakech, Kenitra, and Taiz, respectively. As well, the values radical scavenging activity of methanolic extract of the same concentration, which are $(82.77 \%)$; $(53.33 \%)$ and $(47.5 \%)$. Through it, 50\% inhibition (IC50) was obtained to be (145.6); (179.17) and (274.899) $\mu \mathrm{g} / \mathrm{ml}$ in Marrakech, Kenitra, and Taiz respectively. But regarding the values radical scavenging activity of essential oil of the same concentration, which are $(63.77 \%) ;(42.19 \%)$ and $(80.25 \%)$. Through it $50 \%$ inhibition (IC50) was obtained to be (155.54); (271.158) and (101.31) $\mu \mathrm{g} / \mathrm{ml}$ in Marrakech, Kenitra, and Taiz respectively (Table 8 and Figures4,5,6). We found that the Marrakech region of extracting ethanolic is the highest value of polyphenols and flavonoids by (62.42) and (84.837) $\mu \mathrm{g} / \mathrm{ml}$, respectively, the lowest in the IC50 of value was (92.04) $\mu \mathrm{g} / \mathrm{ml}$. Followed by Kenitra with value are (57.428) and (56) $\mu \mathrm{g} / \mathrm{ml}$ and the value of IC50 is $(153.55) \mu \mathrm{g} / \mathrm{ml}$, the lowest value in Taiz is (55.642) and (44.372) $\mu \mathrm{g} / \mathrm{ml}$ and the value of IC50 is (215.407) $\mu \mathrm{g} / \mathrm{ml}$. Through the results which reached, we find that the oxidation activity and the polyphenols and flavonoids of citrus peels in the Marrakech and Kuneitra region in Morocco are higher than the Taiz region in Yemen.

The reason is due to the influence of citrus fruits of lack of water, environmental conditions, genetic factors, genetic makeup, climate, and distance from the sea.

As well, the content of total polyphenols in the ethanolic extracts is the highest than from the methanolic extracts. This study is conformity with Hegazy Ibrahim (2012) ${ }^{16}$. Who determined a higher value of phenolic $(\mathrm{mg} / \mathrm{g}$ of extract) in Ethanol (169.38) extract rather than Methanol (165.38) extract of orange peel.

The reason is the difference in polarity that made the polyphenol ratio of extracted Ethanol higher than extracted Methanol. Therefore the type of extraction solvent and its polarity may have a significant impact on the level of extracted polyphenols. The polarities of the polyphenols range from polar to non-polar; optimum extraction of polyphenols is usually obtained in the polar solvent, which has a better efficiency of solvation as a result of interactions (hydrogen bonds) between the polar sites of the antioxidant compounds and the solvent than non-polar one ${ }^{17}$. This study differed with Truong, who determined a higher value of phenolic $(\mathrm{mg} / \mathrm{g}$ of extract) in Methanol (13.36) of other solvents extract rather than methanol (165.38) extract of Severinia buxifolia. The reason is that plant materials have a difference in the solubility of polar compounds ${ }^{18}$.

\section{Conclusion}

The present study demonstrated the antioxidant increases activity with increased polyphenols and IC50 deficiency of fresh citrus lemon peel in Marrakech, Kenitra, and Taiz, as well as the difference in the regions which affect the extraction of polyphenols and flavonoids, as well as the oxidation activity. This is the result of environmental conditions, climate, lack of water, and height from the sea, genetic factors, and genetic makeup. In addition to the type of polar solvent, the choice of plant's appropriate solvent and also the harvest season, all affect the result of extraction.

\section{Acknowledgments}

I thank all my family who supports me, my father, my mother, my brothers, sisters and all my friends. Special thanks to Doctor Khedid Khadija about her a considerable effort with me to achieve this humble research.

\section{References}

1- S. Zahoor, F. Anwar, T. Mehmood, B. Sultana, R. Qadir, Variation In Antioxidant Attributes And Individual Phenolics Of Citrus Fruit Peels In Relation To Different Species And Extraction Solvents, Journal of the Chilean Chemical Society, 2016, 61 (2), 2884-2889.

2- R. Ns, H. Sm, Estimation of Phytochemical Content and Antioxidant Activity of Some Selected Traditional Indian Medicinal Plants, Indian J Pharm Sci, 2011, 73 (2), 146-151.

3- A. Owosini, A. Ayansina, O. Amjo, In vitro assessment of the antimicrobial activities of leaf and stem extracts of Alchorneacordifolia, J Appl Sci Environ Manag, 2015, 19(2), 303-308.

4- J. A. Del Rio, M. D. Fuster, P. Gómez, I. Porras, A. Garc' 1a-Lidón, A. Ortuño, Citruslimon: a source of flavonoids of pharmaceutical interest, Food Chem, 2004, 84 (3), 457-461.

5- M. Boluda-Aguilar, A. López-Gómez, Production of Bioethanol by Fermentation of Lemon (Citrus Limon L.) Peel Wastes Pretreated with Steam Explosion, Industrial crops and products, 2013, 41, 188-197.

6- Y. Chen, T. J. Barzee, R. Zhang, Z. Pan, Citrus, Integrated Processing Technologies for Food and Agricultural By-Products, Academic Press, 2019, 217-242. 
7- R. Apak, K. Güçlü, B. Demirata, M. Özyürek, S. Çelik, B. Bektaşoğlu, K. Berker, D. Özyurt, Comparative evaluation of various total antioxidant capacity assays applied to phenolic compounds with the CUPRAC assay, Mol, 2007, 12 (7), 1496-1547.

8- A. Gil-Izquierdo, M. T. Riquelme, I. Porras, F. Ferreres, Effect of the rootstock and interstock grafted in lemon tree (Citrus limon (L.) Burm.)on the flavonoid content of lemon juice, J. Agric. Food Chem, 2004, 52 (2), 324-331.

9- Z. Zou, W. Xi, Y. Hu, C. Nie, Z. Zhou, Antioxidant activity of Citrus fruits, Food Chemistry, 2016, 196, 885-896.

10-J. U. Ewansiha, S. A. Garba, M. Galadima, S. Y. Daniyan, M. B. Busari, Therapeutic Potency of Citrus Limon (L) Burm. F. (Lemon) Peel Extract Against Some Disease-Causing Microorganisms, Int J Res Stud Biosci, 2020, 4(11), 30-39.

11-R. Adams, Identification of Essential Oil Components by Gas Chromatography/Quadrupole Mass Spectroscopy, Carol Stream, 2005, 16, 1902-1903.

12-E. Lister, P. Wilson, Measurement of total phenolicsandABTS assay for antioxidant activity (personal communication), Crop Research Institute, 2001, 36, 718-744.
13-J. D. Ordon, M. A. Gomez, M. I. Vattuone, J. D. Ordon, M. A. Gomez, M. I. Vattuone, Antioxidant activities of Sechiumedule, Swartz extracts, Food Chemistry, 2006, 97, 452-458.

14-B. Huang, H. Ke, J. He, X. Ban, H. Zeng, Y. Wang, Extracts of Haleniaelliptica exhibit antioxidant properties in vitro and in vivo, Food Chem Toxicol, 2001, 49, 185-190.

15-A. Jahanban-Esfahlan, A. Ostadrahimi, M. Tabibiazar, R. Amarowicz, A Comparative Review on the Extraction, Antioxidant Content and Antioxidant Potential of Different Parts of Walnut (JuglansRegia L.) Fruit and Tree, Molecules, 2019, 24 (11), 2133.

16-A. Hegazy, M. Ibrahium, Antioxidant Activities of Orange Peel Extracts, World Applied Sciences Journal 2012, 18 (5), 684-688.

17-X. Liu, M. Dong, X. Chen, M. Jiang, X. Lv, G. Yan, Antioxidant activity and phenolics of an endophytic Xylaria sp. From Ginkgo biloba. Food Chem, 2007, 105 (2), 548-554.

18-P. Kuppusamy, M. M. Yusoff, N. R. Parine, N. Govindan, Evaluation of In-Vitro Antioxidant and Antibacterial Properties of Commelina Nudiflora L. Extracts Prepared by Different Polar Solvents, Saudi Journal of Biological Sciences 2015, 22 (3), 293-301. 